\title{
Reformulation of Local Government Policy Regarding Agricultural Land Transfer Permits to Building Food Security in the Era of the Covid-19 Pandemic
}

\author{
Khrisna Hadiwinata* Shohib Muslim Hudriyah Mundzir \\ State Polytevhnic of Malang, Jl. Soerkarno Hatta no. 9, Malang, Jawa Timur, Indonesia
}

\begin{abstract}
This research is motivated by four main problems, namely philosophical problems, theoretical problems, juridical problems and sociological problems. The philosophical problem is the shift in the value of justice from the community regarding the important value of agricultural land in Indonesia. This research is based on the decline in agricultural land in Indonesia which has been converted into non-agricultural land. Indonesia itself is an agricultural country which in fact agricultural land is a source of commodities and food security for the country. If agricultural land continues to be converted, it will have many negative impacts on the stability of the country. In addition, the environmental ecosystem will be disturbed by changing the function of the land. In addition to the philosophical problems above, there is also a theoretical problem, that with the implementation of a decentralized government system in which each region is authorized and has the right to take care of its own household. In addition, the Covid-19 pandemic that the country is currently experiencing brings many new problems, especially in food security. In addition, the juridical problem is that the Government in this case the central government has anticipated the effects of this agricultural land conversion by passing Law no. 41 of 2009 concerning the Protection of Sustainable Agricultural Land. This law has not been able to even tend to have a crucial article that can be misused by the Regional Head in granting a location permit for the conversion of agricultural land. Even existing laws tend to be deviated by Regional Heads armed with discretionary authority and this is a new challenge, especially in the era of the COVID-19 pandemic. The sociological problem in this study is that the excessive conversion of agricultural land will cause social unrest in the community. This is caused by: (1) agricultural land is exploited into residential land by ignoring the obligation to replace new agricultural land. (2) Exploitation of agricultural land in the region seems not yet fully for the prosperity of the people in the region. And permits are no longer seen as an instrument for controlling the community but as a means of increasing local government tax. (3) The current COVID-19 pandemic is the country's biggest challenge in developing the country's current food security.
\end{abstract}

Keywords: Reformulation, Agricultural Land Transfer, Food Security

DOI: $10.7176 / \mathrm{JLPG} / 114-04$

Publication date:October $31^{\text {st }} 2021$

\section{Introduction}

In this era of the Covid-19 pandemic, the disruption faced by farmers has become increasingly fast, causing the food supply chain to experience serious disruptions. Ironically, some agricultural commodity prices have actually decreased due to falling demand. The decrease in community activities causes the demand for food to also decrease. There are so many culinary sectors that do not run their business so that the demand for agricultural commodities has actually fallen drastically.

The decline in agricultural commodities certainly has a negative impact on the welfare of farmers. When agricultural production continues, while demand in the market falls, there will be an oversupply so that commodity prices will fall. The fall in prices will make farmers reduce their production because they are at a loss. If this is not addressed immediately, then in the future when the pandemic reaches the end point there will be a shortage of food because farmers continue to reduce their production. The fall in food commodity prices has occurred in several areas, such as in Central Java Province. Central Java, which has potential in the agricultural sector, has also been affected by the Covid-19 outbreak. Some food commodities that experienced a decline include chili, vegetables and fruits.

As stipulated in the basic agrarian law in article 6 , it has been stated that all land rights have a social function. This means that any land rights that exist in a person cannot be justified, that the land will be used (or not used) solely for his personal interests, especially if it is adjusted to his circumstances and the nature of his rights, so that it is beneficial for welfare and happiness. who have it and also benefit the community and the country. However, this provision does not mean that individual interests will be totally suppressed by the public interest (community).

Along with population growth and the development of human civilization, land tenure and use began to be disturbed. As a result of population growth and an increase in consumption per capita stimulated by an increase in household income, the need for rice continues to increase. To compensate for this increasing demand, national 
rice production must increase adequately in order to maintain food sufficiency. However, various research results reveal that the growth rate of rice production has recently been getting slower. (Simatupang, 2002).

Actually a number of laws have been made and various regulations have been created, but all of them seem to be sterile in controlling the conversion of agricultural land. In other words, the effectiveness of the implementation of the transfer of function control instrument has not run optimally as expected. Therefore, it is necessary to realize an alternative control strategy, which is based on community participation.

Land conversion or change in the function of land in part or all of the area from its original function as planned into other functions that have a negative impact on the environment and the potential of the land itself. Transfer of function or land mutation in general involves the transformation in the allocation of land resources from one use to another, very much occurs in Java, for example, the change in the function of irrigated rice fields to industrial land, and protected functions to residential land.

The conversion of agricultural land / conversion of agricultural land is very unprofitable, especially in the agricultural sector, related to the productivity of agricultural products. Conversion / conversion of agricultural land has an increasing trend in line with the growth and development of the economic sector and population growth. In fact, most of the conversion of agricultural land is used for settlements, industrial provision, roads and other public facilities.

The conversion of land which was originally for agriculture to non-agricultural land is the main factor in the shortage of agricultural land. In addition to reducing land for agriculture, in the sense of producing food and providing jobs as the main function of the agricultural land, it can also be interpreted that the decrease in fertile land results in the destruction of ecosystems, namely as rainwater absorbers/containers, flood prevention and erosion and protection of the environment. The more frequent floods and landslides is one of the consequences caused by the increasing number of critical lands, whether it is due to the conversion of agricultural land to nonagricultural land or improper land use.

Food commodities fell because the local lockdown caused the distribution of food commodities to be hampered so that many commodities were damaged and their prices fell. In addition, the decline in people's purchasing power due to the spread of layoffs also contributed to a decrease in the absorption of agricultural products. In addition, during this pandemic, many entrepreneurs are unable to run their businesses. Reduced community activities such as celebrations, gatherings, and other activities that usually require large consumption are currently no longer available so that the demand for food decreases In fact, many culinary businesses are closed, resulting in oversupply during the main harvest.

Then, how is the readiness of farmers in food security efforts after the COVID-19 pandemic? We must be optimistic that the farmers are able to provide food for this country. Indonesian farmers are simple farmers because they will continue to carry out their agricultural activities even though they do not know the certainty of commodity prices when harvesting later. Farmers are food heroes for this nation whose welfare must be considered. The readiness of farmers needs to be supported by various policies from the government.

\section{Research Method and Materials}

This research is descriptive analytical which describes the applicable laws and regulations, associated with legal theories in implementation practices related to the problems studied. (Soemitro, 1990; 97-98) The legislation is the Criminal Code, Law no. 41 of 2009 concerning the Protection of Sustainable Food Agricultural Land.

The approach method used is through a normative juridical approach or normative legal research, namely legal research carried out by examining library materials or secondary data. (Soekanto, 2011: 22)

Literature research is by reviewing secondary data consisting of:

1) Primary legal materials, namely binding legal materials. The legal materials are in the form of statutory regulations, namely the Criminal Code, Law no. 41 of 2009 concerning the Protection of Sustainable Food Agricultural Land.

2) Secondary legal materials, namely materials that provide an explanation of primary legal materials, such as draft laws, research results, or legal expert opinions.

3) Tertiary legal materials, namely materials that provide instructions and explanations of primary legal materials and secondary legal materials, such as dictionaries (law) and encyclopedias.

In analyzing the data, it is done by using a qualitative normative analysis method. Normative, namely research departs from research on existing regulations, both written and unwritten legal regulations as positive norms. Qualitative, namely data analysis based on efforts to find principles and information to achieve clarity of the problems discussed by not using mathematical formulas.

\section{Results and Discussion}

In this era of the Covid-19 pandemic, the disruption faced by farmers has become increasingly fast, causing the food supply chain to experience serious disruptions. Ironically, some agricultural commodity prices actually decreased due to falling demand. The decrease in community activities causes the demand for food to also 
decrease. There are so many culinary sectors that do not run their business so that the demand for agricultural commodities has actually fallen drastically.

The decline in agricultural commodities certainly has a negative impact on the welfare of farmers. When agricultural production continues, while demand in the market falls, there will be an oversupply so that commodity prices will fall. The fall in prices will make farmers reduce their production because they are at a loss. If this is not addressed immediately, then in the future when the pandemic reaches the end point there will be a shortage of food because farmers continue to reduce their production.

Food commodities fell because the local lockdown caused the distribution of food commodities to be hampered so that many commodities were damaged and their prices fell. In addition, the decline in people's purchasing power due to the spread of layoffs also contributed to a decrease in the absorption of agricultural products

In addition, during this pandemic, many entrepreneurs are unable to run their businesses. Reduced community activities such as celebrations, gatherings, and other activities that usually require large consumption are now no longer available so that the demand for foodstuffs decreases. In fact, many culinary businesses are closed, resulting in oversupply during the harvest season.

Then, how is the readiness of farmers in food security efforts after the COVID-19 pandemic? We must be optimistic that the farmers are able to provide food for this country. Indonesian farmers are humble farmers because they will continue to carry out their agricultural activities even though they do not know the certainty of commodity prices when harvesting later. Farmers are food heroes for this nation whose welfare must be considered. The readiness of farmers needs to be supported by various policies.

One of the policies is market adaptation is one way that needs to be taken. Farmers need to adjust to the situation in the midst of this pandemic, especially market conditions. Some commodities that may decrease in demand need to be replaced with commodities with better market prospects. For example, hydroponic farmers of various lettuce whose market segments were initially hotels, restaurants and malls, which currently have reduced prospects, can turn to kale or mustard farmers whose market is still good because the market segment is all people.

The stability of agricultural commodity prices needs to be maintained so that commodity prices do not fall too much so that farmers are still willing to produce food, the Government can work together with several cooperatives and BUM-Des to help farmers market their products so that farmers do not experience marketing problems. Farmer cooperatives in villages can also be a provider of capital for farmers because the condition of farmers' capital in the midst of a pandemic like this is very weak.

Online agricultural commodity marketing platforms can be used to assist farmers in marketing their harvests, Ease of access for farmers to production factors such as fertilizers, seeds and irrigation channels must be guaranteed, Emergency food reserve management. In the midst of the current Covid-19 emergency, food ingredients must be available in good quantity and quality and at affordable prices.

One of the innovations that are often carried out and considered good for protecting families from the impact of the food security crisis, at least per household, is urban farming. Many examples have been done by many people from urban farming, such as planting rice in home gardens (non-rice fields), hydroponic rice plants, planting short-lived rice, or rice plants integrated with fish farming.

To safeguard the needs of the community and avoid a food security crisis, the Ministry of Agriculture as a technical institution responsible for agriculture (food) has also prepared various strategies to face the challenges of food security during the pandemic.

Some of the programs that have been prepared include the following: - Capacity building through food estates - Diversification of food production and consumption - Facilitation of food reserves in various regions Facilitation of marketing of agricultural commodities through named Toko Tani Indonesia ( Indonesian Farmer Shop ) Several social safety network packages.

Experts remind that maintaining food security in the midst of the crisis due to the Covid-19 pandemic cannot only be done by policymakers, but the community must also be involved, so that at least they can maintain the food welfare of individuals and their own families. According to the World Food Summit (1996), food security occurs when all people, at all times, have physical and economic access to meet their needs and preferences for sufficient safe and nutritious food for a healthy and active life. This can be identified from four indicators, namely physical availability of food, economic and physical access to food (economic and physical availability), food utilization, and the stability of the three indicators.

If you look at these indicators, to maintain food security, it is not enough to only focus on the community or the government. There needs to be synergies and efforts starting at the individual, household, community, private sector (company), and government levels as policy makers.

Policy formulation as a process according to Winarno can be seen in 2 kinds of activities. The first one is to generated what to do or in other formulation is directed to obtain the agreement on an alternatives policy to chose, a decision that agrees is the result of the whole process. Meanwhile, the next activity directed at how 
policy decisions made, in this case a policy decision includes action by an official or official institution to approve, change or reject an alternative the chosen policy ( Winarno 2011 : 94 ). Formulation of land us change the policy control of agriculture, hereinafter better known as policy about this sustainable food agricultural land also more likely to use the problem approach in formulating policy.

Law of the Republic of Indonesia Number 41 of 2009 which is meant by Sustainable Food Agricultural Land is a field of agricultural land that is determined to be protected and developed consistently in order to produce staple food for national food self-reliance, security and sovereignty. Availability of agricultural land for food is closely related to several things, namely: 1) Potential of food agricultural land resources, 2) Land productivity, 3) Fragmentation of agricultural land, 4) Scale of agricultural land tenure, 5) Irrigation system, 6) agricultural land rent , 7) Conversion, 8) Farmer's income, 9) Agricultural human resource capacity and 10) policies in agriculture.

The policy alternatives taken are basically a compromise of the various interest groups involved in the formation of the policy and have binding legal force. Policy determination can take the form of laws, jurisprudence, presidential decrees, ministerial decisions and so on. As a concrete step, the Ministry of Agriculture through the Agency for Extension and Development of Agricultural Human Resources has formulated a Method of 4 Ways of Action to achieve food security. First, increasing production capacity. The Ministry of Agriculture invites agricultural actors to accelerate the planting of rice planting Season II 2020 covering an area of 6.1 million ha, the development of swampland in Central Kalimantan Province to 164,598 ha, including the intensification of 85,456 ha of swamp land and the extensification of 79,142 ha of agricultural land. Second, local food diversification. The Ministry of Agriculture will develop local food diversification based on local wisdom that focuses on one main commodity. Third, strengthening food reserves and logistics systems by strengthening provincial government rice reserves, then strengthening district/city government rice reserves. Fourth, the development of modern agriculture, through the development of smart farming, the development and use of screen houses to increase the production of horticultural commodities outside the growing season, the development of farmer corporations, and the development of food estates to increase the production of main food (rice/corn).

The Ministry of Agriculture also has short, medium and long term agendas in dealing with the Covid-19 pandemic. In the short term, the emergency agenda includes maintaining food price stability and building buffer stocks. The medium-term agenda is realized by continuing post-Covid-19 labor-intensive activities, diversifying local food, helping food availability in deficit areas, anticipating drought, maintaining agricultural work spirit through assistance for production and machinery and equipment, encouraging family farming, helping smooth food distribution, increasing agricultural exports, strengthen Kostratani. Meanwhile, the long-term (permanent) agenda is carried out, among others, by encouraging an increase in production by $7 \%$ per year and reducing losses to $5 \%$.

\section{Conclusion}

The influence of power and strategy in decide on a program, the more they make land conversion policies as the rules in the city planning are becoming more and more complicated. Because political power is very influential in in it. In general, authors can see how the concept of implementing this policy affects the implementation of the land conversion policy.

The local government's impartiality towards regulations that do not in accordance with the real conditions of a district, and population growth factors in Indonesia, the height becomes necessary priority in this case. Uncontrolled conversion of agricultural land can threaten food supply capacity, and even in the long term can cause social losses.

The strategy for controlling the conversion of agricultural land that relies on community participation is to involve the active participation of all stakeholders as entry points for planning, implementing, monitoring, and assessing (focusing analysis) existing laws and regulations. However, it should be underlined that community participation will not be realized if it is not accompanied by approaches in the form of socialization and advocacy.

The national food security index had dropped from 44.10 to 40.10 in the first two months after the pandemic broke out. In responding to these conditions, the writers considers that local governments need to coordinate with the central government and a number of stakeholders to strive for massive use of local food. Of course, this can be adapted to the local food culture of the region such as cassava, corn, sago, bananas, potatoes, and sorghum. The government is aware of the risk of a food crisis if the pandemic is prolonged. To that end, the government has taken several efforts, such as by conducting a program to expand new planting areas of nearly 165,000 hectares in Central Kalimantan Province to increase food availability, that dependence on imports will be dangerous if the crisis persists for a long time. We must be based on local economic development, especially at the village and headman level, and provide support to local producers. 


\section{References}

Amrah Muslimin, Beberapa Asas Dan Pengertian Pokok Tentang Administrasi Dan Hukum Administrasi, Penerbit Alumni, Bandung, 1985

Ateng Syafrudin, Menuju Penyelenggaraan Pemerintahan Negara yang Bersih dan Bertanggungjawab, Jurnal Pro Justicia Edisi IV, Universitas Parahyangan, Bandung, 2000

Budi Winarno, Kebijakan Publik: Teori dan proses, Med press (Anggota IKAPI), Yogyakarta, 2011

Dennis A, Rondinelli, et. al.,. Government Decentralization in Comparative Perspective Theory and Practice in Developing Countris, Intemational Review of Adminstration Science, Vol.XL VIL No.2., 1981

E. Utrecht, Pengantar dalam Hukum Indonesia,, Ichtiar, Jakarta, 1957

Hanif Nurcholis, Teori dan Praktek Pemerintahan Daerah, Grasindo, Jakarta, 2005

I Gde Pantja Astawa, Hak Angket Dalam Sistem Ketatanegaraan Indonesia Menurut Undang-Undang Dasar 1945, Disertasi, Univ. Padjadjaran, Bandung, 2000

Indroharto, Asas-Asas Umum Pemerintahan yang Baik, dalam Paulus Efendie Lotulung, Himpunan Makalah Asas-Asas Umum Pemerintahan yang Baik, Citra Aditya Bakti, Bandung, 1994

Irawan Simatupang, et al, Pengendalian Konversi Lahan Pertanian : Tinjauan Ulang kebijakan Lahan pertanian abadi. Makalah Seminar Nasional “Multifungsi dan Konversi Lahan Pertanian”, 25 Oktober 2002, Badan Penelitian dan Pengembangan Pertanian, Departemen Pertanian, Jakarta , 2002.

Ismail Suny, Mekanisme Demokrasi Pancasila, Aksara Baru, Jakarta, 1984

Michel Parenti, Democracy for the Few. Fifth Edition, St Martin's Press, New York, USA, 1988

Miriam Budiardjo, Dasar-Dasar Ilmu Politik, Gramedia Pustaka Utama, Jakarta, 1998

Philipus M Hadjon, Tentang Wewenang, Makalah, Universitas Airlangga, Surabaya

Prajudi Atmosudirdjo, Hukum Administrasi Negara, Jakarta, Ghalia Indonesia

Rusadi Kantaprawira, Hukum dan Kekuasaan, Makalah, Universitas Islam Indonesia, Yogyakarta, 1998

Ronny Hanitijo Soemitro, Metodologi Penelitian Hukum dan Jurimetri, Ghalia Indonesia, Jakarta, 1990

Sudikno Mertokusumo, Upaya Meningkatkan Supremasi Hukum, dalam Majalah Justitia Et Pax, Fakultas Hukum Univ. Atmajaya, Yogyakarta, Edisi Bulan Mei-Juni 2000 Thn. XX Nomor 19

Suwoto Mulyosudarmo, Kekuasaan dan Tanggung Jawab Presiden Republik Indonesia: Suatu Penelitian Segi-Segi Teoritik dan Yuridis Pertanggungjawaban Kekuasaan, (Surabaya: Universitas Airlangga, 1990), Hlm. 30

Sondang P. Siagian, Patologi Birokrasi, Mizan, Jakarta, 1998

Soerjono Soekanto dan Sri Mamudji, Penelitian Hukum Normatif - Suatu Tinjauan Singkat, Rajawali Pers, Jakarta, 2011

Sri Soemantri Martosoewignjo, Undang-Undang Dasar 1945, Kedudukan dan Artinya dalam Kehidupan Bernegara, Makalah yang disampaikan pada Stadium Generale dan Peringatan 40 Tahun Pengabdiannya di Univ. Padjadjaran Bandung, Bandung, 2001

Sjahran Basah, "Pencabutan Izin Salah satu Sanksi Hukum Administrasi, Makalah dalam Penataran HAN dan Hukum Lingkungan, Unair Surabaya, 1995, hlm. 1-2

Law no. 41 year 1999 about Sustainable Agriculture Land

Law No. 23 year 2014 about Local Government 